\title{
Tradition and interpretation: Twenty-five attempted approaches - in honour of E Earle Ellis
}

\author{
Herman A Lombard \\ University of South Africa
}

\begin{abstract}
Tradition and interpretation: Twenty five attempted approaches - in honour of E Earle Ellis
\end{abstract}

In a collection of essays in honour of prof E Earle Ellis twenty-five scholars surveyed the present (1987) state of New Testament scholarship and presented their own contributions. The title, Tradition and interpretation in the New Testament, epitomises the paradigm by means of which the authors dealt with issues such as methodology relating to New Testament studies, the meaning and significance of crucial New Testament passages and some New Testament theological themes. The present author contends that the qualification 'attempted approaches' in the subtitle of this article spells out that a scrutiny of the articles displays that the authors did not investigate interpretations of traditions in the New Testament, but that they rather present their diverse interpretations of the various versions of early-Christian traditions contained in the New Tesatament.

\section{INTRODUCING E EARLE ELUS AND THE 'FESTSCHRIFT'}

In a recently published collection of essays twenty-five scholars from WesternEurope, the United Kingdom and the United States of America honoured Professor E Earle Ellis at the occasion of his sixtieth birthday. This book, entitled Tradition and interpretation in the New Testament, was edited by Gerald Hawthorne and Otto Betz, and published in 1987 together by Eerdmans at Grand Rapids (USA) and JCB Mohr (Paul Siebeck) at Tübingen. 
Prof Ellis, in 1987 a Professor for research at the Southwestern Baptist Theological Seminary in Fort Worth (Tx), visited South Africa in 1986 as a guest professor of the University of Stellenbosch and he also then delivered lectures at most of the Universities of this country.

Apart from eight academic honours and nine lecturing posts at various institutions, his publications during the years 1956-87 count an impressive ninety-six. During the two decades since 1967 he was a visiting guest lecturer for semesters and shorter terms at more than seventy institutions in the United States of America, Western Europe, United Kingdom and also the Republic of South Africa.

By writing and publishing this book a number of his colleagues wanted to honour their fellow-schollar prof Ellis for his superb academic work, the services he as theologian rendered to the church at large and for his devotion as Christian believer.

This publication comprises three sections which contain six, nine and ten contributions respectively by the twenty-five authors. These essays vary widely from each other regarding ways of approach, the context of observations and the authors' academic competence in their respective fields of specialisation. In general, the reader is informed here about the recent state of affairs in research work and he/she is also introduced to certain fields of study and some issues as they are clearly reflected in the titles of the essays. They are the following:

Proclamation (of New Testament Christianity) and response (in faith) (by CK Barrett)

Example (from Scriptures) and precept (for life and religion): From Sirach to $R$ Ishmael (by David Daube)

Three ways of understanding relations between the testaments: Historically and today (by Richard N Longenecker)

Is apocalyptic the mother of Christian theology (by I Howard Marshall)

Jesus, Judaism and Paul (by CFD Moule)

- Gottes- und Menschenliebe im Neuen Testament (by Georg Strecker)

Paul's use of the Old Testament in Acts (by FF Bruce)

John and the Synoptics: Can Paul offer help? (by Peder Borgen)

The law and the prophets in $Q$ (by David R Catchpole)

Aramaic evidence affecting :he interpretation of 'Hosanna' in the New Testament (by Joseph A Fitzmyer, SJ)

The role of the Christian prophets in the gospel tradition (by Gerald F Hawthorne) Jesus - the son of God, the stone, the son of man, and the senvant: The role of

Zechariah in the self-identification of Jesus (by Seyoon Kim) 
Die Wundergeschichten von Mt 8-9 (by Ulrich Luz)

John, the Synoptics, and the canonical approach to exegesis (by D Moody Smith)

The origin and purpose of Matthew's sermon on the mount (by Graham $\mathrm{N}$ Stanton)

Der gekreuzigte Christus: Unsere Weisheit und Gerechtigkeit (der alttestamentliche Hintergrund von 1 Kor 1-2) (by Otto Betz)

'Righteousness from the law' and 'righteousness from faith': Paul's interpretation of Scripture in Rom 10: 1-10 (by James DG Dunn)

'Le Seigneur de tous' (Ac 10: 36; Rm 10: 12) (by Jacques Dupont)

Code and context: A few reflections on the parenesis of Col 3: 6-4: 1 (by Lars Hartman)

Der Jakobusbrief als antipaulinische Polemik (by Martin Hengel)

The opponents of Paul in 2 Corinthians: An old issue revisited (by Ralph P Martin)

Judgment and the brother: Romans 14:1 - 15: 13 (by Wayne A Meeks)

Gospel traditions in the church in Corinth (with apologies to BH Streeter) (by Peter Richardson)

Nochmals: Paulusakten und Pastoralbriefe (by Willy Rordorf)

The hermeneutical significance of 1 Cor 2: 6-16 (by Peter Stuhlmacher).

\section{METHODOLOGY FOR REVIEWING SUCH COLLECTIONS OF ESSAYS}

This survey of the titles of the twenty-five essays clearly displays the divergent nature and wide scope of this publication. This fact obviously complicates the task of a detailed review of a work such as this one. Where the authors are supposed to be specialists it entails that only a fellow-specialist in the same field can make a thorough and complete assessment of each essay. In our own time where theologians specialise in specific fields very few (if any at all!) scholars of reputation would claim for themselves the academic 'charisma' of such a comprehensive scholarly ability by which they could thoroughly assess such a collection of essays by alleged specialists.

While I claim for myself this realistic attitude of modesty and I also maintain a due esteem for prominent theologians, I would like though to do justice to my assignment to review this book. To do so, I deem the following rules of procedure to be important:

- The academic standing of each one of the contributors should properly be taken into account. 
- The policy and academic prestige of the publisher(s) offer some directive as to whether the publication can be expected to be assessed in a positive, or a neutral or a negative way.

- This policy and viewpoint of the publishers and editors should be weighed critically by looking at the extent to which the contributors were allowed to exercise their academic freedom and deploy their academic strength in full. In this respect it must be stipulated here that scientific publications should not be judged by perceptions such as those denoted as 'conservative' and 'liberal', since these terms are invalid here. The reason for asserting this is simply that judgments by these norms and this type of assessment are based on a much too narrow-minded selectivity regarding theological perspective, norms and the procedure of judging others' viewpoints. It also breathes a sense of selfassertiveness because it takes the own perspectives, norms and procedures as being universally valid and as having the exclusive claim on truth and legitimacy. Such an attitude is the result of the process of absolutising the own hermeneutical paradigm and of the (usually only one!) exegetical method.

* A reviewer is entitled to express a critical judgment on those essays which deal with his field of specialisation. In doing this, his scrutiny should include also, amongst all other things, an exact check on the dates of the publications a contributor referred to.

\section{PRELIMINARY ANTICIPATED ASSESSMENT OF THE BOOK}

As far as the first three rules of procedure are concerned, one can, in general, expect a favourable and positive judgment on the publication under discussion. This general positive judgment on the presumed high standard of both editors and publishers is confirmed by their choice of the contributors. By far the majority of them are honourable scholars who need not fear to be judged on the methodological level of their paradigms of understanding the primary source (the Bible), as well as on their presuppositions, vantage points, their perceptions on their task as exegetes and theologians within the frames of reference in which they investigated particular problems/issues in and relating to the New Testament.

Furthermore, in general there are three other prima facie reasons for being positively inclined about this publication. These are:

Firstly, it contains a very useful and extensive index of scripture references, covering fifteen pages (pp 349-363). This index furnishes references to the Old- and New Testaments as well as to the Apocrypha and Pseudepigrapha of both Testaments. This confirms the fact that most of the authors covered a wide field in their 
investigation of the contents of the primary sources for New Testament studies.

Secondly, an index of modern authors which refers to the works of about fivehundred-and-sixty-one scholars demonstrates the extent of reading work done and scholarly competence of most of the authors and re-affirms the fact that a major step in a correct method of research is taking cognisance of other scholars' work and entering into critical discussion with them on their results of research. While most of the contributors formally fulfilled this prerequisite, only a specialist's assessment of the contents of each one of the essays would however verify whether or not the authors' discussions with other scholars had been adequate and legitimate in real terms.

Thirdly, a survey of the dates of publications mentioned in the bibliographies shows that formally the majority of the authors took cognisance of the latest results of others' research work. Again, only a specialist would be able to finally establish to what extent each one of them has made a complete, or at least a representative projection of the state of research and whether or not each one has responded legitimately to it.

In terms of stipulation above that a detailed assessment of each essay could be done only by a specialist in that field of study, I restrict my assessment to contributions in the Johannine field, especially the Fourth Gospel.

The relevant essays here are those of Peder Borgen (pp 80-94) and D Moody Smith (pp 166-80). Except for these two essays particularly on some Johannine issues in the Fourth Gospel, ten of the other authors brought this Gospel into discussions of other issues. These are $C K$ Barrett (pp 9, 15 according to which Jh 17: 25 on p 356 should read Jh 17: 26), CFD Moule (p 47), Georg Strecker (pp 56, 61f, 65f), FF Bruce (p 77), Joseph Fitzmyer (pp 110, 113), Gerald Hawthome (pp 123.25, 127f, 130, 132), Otto Betz (pp 199f, 210), Marin Hengel ( $\mathrm{p} 262$ ), Peter Richardson (pp 306, 316) and Peter Stullmacher (pp 341f).

Before Bergen's and Smith's essays can be discussed in detail, I would like first to make some critical remarks on the way that some of these other ten scholars used, or abused John's gospel.

\section{PROPER REVIEW: ASSESSMENT IN DETAIL}

$C K$ Barrett investigated the problem the apostles and the early church had faced, namely that it acquired a sense of historical realism so that, amidst milieus where established cultures prevailed, they could make their proclamation intelligible within their audiences' frame of mind and make them also respond to their kerygma (p 8). According to Barrett John's Gospel displays that Johannine theology had to 
reckon with a pure gnostic form of thinking. This can be gleaned from, inter alias, Jn 17: 3 which functions for Barrett as a locus classicus for his viewpoints. Barrett rightly observes that the proof whether the apostles' communication with their audiences had been successful, will be given by analyses of the narratives depicting the responses, such as 1 Th 1: 9-10. To Barrett's mind such an analysis affirms his observation that John's community was a quasi-gnostic community in which love more than knowledge ('gnosis') dominated (referring to Jn 17: 26).

What is of importance here in Barrett's essay is his attention to the correlation between the proclamation of the early-Christian message and the response of the audience. This observation is in line with what presently prevails in some theological circles, namely the high priority of interest that many exegetes have in the aspect of the audience/reader, the pragmatics of texts, reader-response criticism and the reading of Biblical texts by means of some or other model of communication. In this respect Barrett's essay deserves merit.

However, serious objections must be raised when he asserts without more ado that gnosticism would be the only and exclusive frame of reference of the Johannine community. In view of all the research work that has been done on the background of John's Gospel such an oversimplification is rather shocking. Furthermore, whereas Barrett incorporates this perception into his paradigm of understanding John's Gospel this must inevitably lead to false results, especially because Jewish and Judaistic elements cannot be ruled out at all. Elsewhere I have reasoned out this through a literary-critical analysis of the Fourth Gospel (see HTS 43, 1987, 395-413). Barrett's biased viewpoint is not at all surprising when one looks at his meagre attestation for his assumption: he refers to three sources only, viz JL Martyn (1968) and two of himself, one dating from 1956(!) and the other one from 1982.

In his essay entitled 'Jesus, Judaism and Paul' CFD Moule refers to Jn 15: 6 in the context of the relationship between the old- and new covenants. No further commentary is needed here.

Georg Strecker's essay 'Gottes- und Menschenliebe im Neuen Testament' offers no fresh information on this subject. His linguistic-theological investigation confirms that the concept of $\dot{\alpha} y \dot{\alpha} \pi \eta$ refers to the vertical and horizontal levels of relations and that it should come to real effect on both these levels. He rightly emphasises the fact that John's Gospel speaks about love for the brother (which includes all of mankind) instead of for/to the neighbour (as the Synoptics have it). This idea, Strecker rightly says, is in line with the cosmic dimension and the missionary perspective underlying the whole gospel.

Strecker ( $p$ 62) maintains his well-known viewpoint about the priority of 2 and 3 John over against the gospel and the remainder of the Corpus Johanneum. He sub- 
stantiates this interesting hypothesis by means of his methodology and his trend of thought elsewhere. As everywhere else, the question arises here whether the assumptions and vantage points can be accepted with such definiteness as practitioners of Traditions- and Redaktionsgeschichte on the Fourth Gospel usually do?

FF Bruce incidentally refers to Jn 12: $39 \mathrm{f}$ as proof of the fact that the Jews rejected Jesus and his gospel. This reference is of minor importance.

Joseph Fitzmyer discusses the Jewish background of the use of the word 'Hosanna' in the New Testament (see Mk 11: 9; Mt 21: 9; Jn 12: 13). He observes that in comparison with its Old Testament usage this word had undergone a shift in meaning during the first century AD. In Ps 118 (LXX 117): 25 the term denotes a call for help from God, whereas in the New Testament it signifies the call/greeting to/of the pilgrims entering Jerusalem. John's Gospel is the closest to the Septuaginta version since it cites it verbatim and only adds '...and/even the king of Israel' (see $p$ 113f). Fitzmyer ( $p$ 110) rightly makes the valuable observation that the translators of the LXX did not transcribe or borrow the Aramaic word 'Hôsi 'ah na', but that

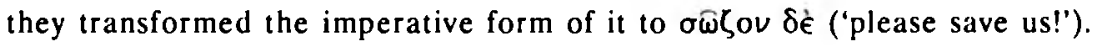
According to Fitzmyer this means that since nowhere the imperative form is transcribed or adopted as a Semitic loan-word, the citation in Jn 12: 13 (and the synoptic parallels mentioned above) was not from the LXX text. My own controlling investigation established this observation. All this implies the reopening of the important debate on the issue about which document/record of the Old Testament formed the text/ source for the early church: the $L X X$ or the Tenach or perhaps some or other unknown document of the traditions.

Gerald Hawthorne presents his essay on 'The role of the Christian_prophets in the gospel tradition'. His working hypothesis is that early-Christian prophets, such as the apostles, were very much creative in that they made additions to the early traditions of the gospels, especially to Jesus' logia (see pp 123, 132 n 20). He critically scrutinises the hypotheses and observations of scholars such as DE Aune (1972), FW Beare (1967), R Bultmann (1963), EE Ellis (1969), E Käsemann (1969), $\mathrm{N}$ Perrin (1967) (see p 132 n 20). He rightly questions scholars' methodology and the proofs they present in substantiating their views, especially their common assumption that some pronouncements recorded as being words of Jesus are in actual fact creations of prominent early-Christian prophets. Although he agrees with Aune and Bruce that ultimately no such legitimate proofs exist, he asserts that the New Testament makes no sharp distinction between Jesus' spoken words and those of the apostles, since the apostles spoke on the authority of Jesus. In this respect he appeals to a proof-text such as $J n$ 13: 10 , consisting the statement: '... those who hear you, have heard me'. 
This observation is however farfetched and invalid. The reason is that a thorough literary investigation of John's Gospel shows that, except for the classical case of Jn 3: 10-21, Jesus' words and his long discourses are clearly distinguished from any form of commentary ('asides') of apostles or the author of/narrator within the Fourth Gospel (for studies and contributions on authors' commentary, see my observations in HTS 43, 1987, 395-413).

Furthermore, Hawthorne's substantiation of his hypothesis by reference to texts, including John's Gospel, is nowhere convincing. This is due to the fact that serious hermeneutical as well as exegetical objections must be raised against his understanding and exposition of texts (see above). That this is the case, is clearly demonstrated by his use of texts such as Ac 16: 16f, Jn 14: 15-18, Rm 8: 9b-10, 2 Cor 3: 17 and an argumentation which runs as follows: The Joel-prophecy was fulfilled when the Holy Spirit of Christ indwelt in the early church in those latter days of the early church. The church then expected from some of its members to prophesy. This prophetic activity comprised a creative transmission of the words of the living Lord after his death, while it also demonstrated the fulfillment of Jesus' promise to them in Mt 18: 20 (viz that where two or three gather in his name there he himself shall be present).

Such a patching together of these texts without thoroughgoing exegesis displays a methodological naivité. His argument (see p 124) about Jesus' promise to his disciples based on Jn 16: 12-15 (the Holy Spirit will soon reveal more of the truth and will teach them) stands on more firm ground. His interpretation here accounts at least for the fact that the wider context of this pronouncement is that it forms part of John's version of Jesus' farewell discourses. However, when he drags in texts such as Ac 16: 6f and passages from the above mentioned texts from the corpus Paulinum, which all deal with the indwelling of the Spirit of wisdom in the apostles and their kerygma, then his argumentation creates three serious problems.

First, it is almost impossible to accept that these texts could serve as substantiation for the hypothesis that the apostles' prophetic words became blended with those of the historical Jesus.

Second, Hawthorne's usage of these texts does not do justice to the immediate context and hard core of these texts. At the utmost these texts allow one to assert that the apostles' preaching took place by the strength of the indwelling Spirit of divine wisdom, through which they proclaimed the crucified and exalted Lord (see Paul's dictum in 1 Cor 2: 1-2; 2 Cor 4:5). Nowhere a single word can be detected about their words being added to those spoken by the earthly Jesus. Nonetheless, was it Paul's intention to testify to the fact that Jesus' promises in his farewell speeches in Jn 14-16 were fulfilled and made real in the apostles' prophetic abilities 
and activities?

Third, in view of the chronological sequence of the events of the writing of documents within the early church, the (pseudonymous) evangelists could have added apostolic words to Jesus' words. The argument then runs as follows: If the apostles had received from Jesus and the Spirit the calling and ability to make such additions to the Lord's words, then what Paul 'prophesied' and wrote in his epistles could have been implemented later in time by the evangelists, since the Pauline epistles were written prior to the gospels. However, literary criticism teaches us that the narrated time (the temps de l' histoire, historical framework of the narrative) of the Gospels goes back to a time prior to that of the apostles! Hawthorne does not deal with this type of problem as addressed by historical-critical and literary-critical investigations.

Hawthorne ( $p$ 127) adduces a further argument for his hypothesis. He maintains that it is proven by the fact that passages such as Jn 7: 53-8: 11 and the longer ending of Mark's Gospel (both which do not occur in the oldest manuscripts) were anyhow accepted in some of the major canons of the churches. According to him these passages were not so much drawn from later oral traditions, than that they originally stemmed from oracles of Christian prophets. By observing this, he utilises textual criticism to prove his point. Methodologically I find this rather farfetched, because such an observation can by no means be gathered from the results of the science of textual criticism. This discipline establishes in this respect only that these passages occur in rather late textual testimonies and that they were acceptable only within certain families of texts as represented by some churches. The later dating and weak attestations of these variant readings make it precisely highly unlikely that the early-Christian prophets should have added these words at an early stage to the primary traditions about Jesus' words. Moreover, Hawthorne is reminded of the fact that textual criticism functions primarily on the level of information about the history of texts of the New Testament and not on the level of dealing with a theology of the canon. In other words, it was a textual-critical and not a theological decision of philologists to stipulate that the oldest texts in the 'best' manuscripts contain the most authentic traditions. On account of this decision these traditions were only later in time deemed by the churches to be most authorative and therefore canonical traditions. Hawthorne's text-critical argument is untenable because it is methodologically invalid, proving historically precisely the opposite of what he purported to prove.

Ultimately Hawthorne's essay must therefore be assessed rather negatively. His hermeneutical paradigm, exegetical method(s) and the methodology of his argumentation for his hypothesis on the ground of $\mathrm{Jn} 16: 12-15$ as a locus classicus are 
greatly suspect, invalid and very much forced.

Otto Betz's contribution consists of an essay on the Old Testament background of 1 Cor 1-2. His investigation was on the theme of the crucified Christ as being the wisdom and righteousness for theology, believers and the church. In honour of Ellis his essay is also a discussion of the former's book, entitled Prophecy and hermeneutics in early Christianity (Tübingen, 1978). Betz investigated issues of hermeneutical and methododological nature, especially the crucial issue of the prophecyfulfillment paradigm. On account of a critical investigation he approves of the viewpoint that the Synoptics, John's Gospel (in 2: 12 and 12: 16) and Paul (in 1 Cor 1-2) picked up their ideas directly from Is 52: $15 \mathrm{ff}$. However, the reference to Jn 2: 12 is a misprint and it should read Jn 2: 22.

With a view to a more representative understanding of John's Gospel the following critical remarks should be made against Betz's approach:

- Viewed from a literary-critical perspective, both texts from John's Gospel (2: 22 and 12: 16) happen to be the commentary ( $\mathrm{e}$ 'asides') of the author of the Fourth Gospel whereby the readers are informed about what had happened earlier during Jesus' earthly ministry. As such it forms part of 'John's' interpretation of the Christ-event and Jesus-logia and of his theological reflection on it. These two texts display some or other element of hermeneutics of a section of early Christianity, namely within the Johannine church. Both in view of the distinctiveness of this church and the context of the Fourth Gospel that was created by it, it is highly questionable whether this Johannine perception can be taken as representative of what prevailed within early Christianity at large.

- The only valid observation to be made from these two texts from John's Gospel is that people within the Johannine church and its theology perceived of OldTestamental traditions in their understanding, explanation and interpretation of Jesus' deeds and logia.

- These two texts offer no direct Old Testament citations, but only general allusions to Old Testament traditions.

- The relationship which Betz constitutes between Is 52: 12ff and these Johannine texts is very much suspect. It can only be conceded that Jn 2: 22 could perhaps be linked with the general undertone of the passage from lsaiah, provided that a particular hermeneutical and exegetical frame of reference is assumed. The Old Testament reference at Jn 12: 16 in the Greek New Testament is not to Isaiah, but citations from Ps 118: 25f and Zch 9: 9 (see remarks on Fitzmyer's 
article above). It is disappointing that a scholar such as Betz treats John's Gospel in such an uncritical way!

Betz observes ( $p$ 210) that according to Jn 6: 3ff and 17: 1ff God communicates his creative power to mankind by means of the kerygmatic word (Bible) and the message of the cross. He asserts this by strength of his paradigm which accounts for the fulfillment of the old covenant by/in the new one, in the sense that in Jesus' own proclamation God appeared and acted as a good Father. The effect of this was that the Christian community lived from both the gift of the Spirit and the charismata which He bestowed on them. This is still the case.

The metaphor of the manna and the bread of life in Jn 6 offers a good example of how 'John' reports Jesus as one combining Old- and New Testament traditions. By observing this, Betz contributes to promote the central theme of his article. However, one cannot accept the way in which he without more ado patches up a bundle of selected texts from the Old Testament, the synoptic Gospels and John's Gospel (even Jn 17 from the farewell speeches). As far as the Fourth Gospel is concerned Betz's treatment is quite an unfortunate and abusive one.

Together with due appreciation for the merit of this article, the criticism mentioned above should be considered when Betz's treatment of 1 Cor 1-2 is assessed. Only after this critical reading one will accept his valuable conclusion (see $p$ 210, par 2):

In der Auslegung von Jes 53 tritt das Neue, Andersartige des christlichen Glaubens gegenüber der jüdischen Auffassung vom Weg zum Heil, zur Gerechtigkeit vor Gott und zur messianischen Erlösung deutlich hervor. Der scharfe Gegensatz zwischen dem sola gratia aufgrund des Kreuzes und dem sola lege der jüdischen Ethik sollte stets erklärt, aber nicht abgeschwächt werden.

Martin Hengel investigated the question whether or not James' letter can be viewed as an anti-Pauline polemic. His vantage point is the observation that this problematic letter contains many unsolved contradictions. He labels the letter as a circular letter which is a 'Meisterstück fruhchristlicher Polemik' ( $p 253$ ). Hengel maintains that the author polemised against what he calls 'einem tatenlosen ScheinGlauben' whereby it became a piece of anti-Pauline polemic ( $p 252$ ).

At the end of his article he indicates that the end of the letter (ch 5) spells out the message of reconciliation even for those who went astray. In this context he refers to $\mathrm{Jn} 1: 29,1 \mathrm{Jn} 2: 2 \mathrm{f}$ and 1 Cor 15: 3 in substantiating his assertion that 'nach 
urchristlicher Anschauung war es Christus, der die menschliche Sünde tilt'. He then cbserves that otherwise James' letter has nothing to say on this important issue, while the letter is in actual fact a Fremdkörper in the corpus of early-Christian writings.

Methodologically it is not in order to cite, interpret and treat the testimony of John the Baptist (as reported by John's Gospel) in such an unnuanced way together with other passages with a view to making such an important assertion about a fundamental trend within early-Christian traditions and its theology. My firm objection against such an approach is that the only correct procedure will firstly be to correlate the Baptist's testimony in John's Gospel with the Synoptics' report on it in Mk 1: 1-8, Mt 3: 1-12 and Lk 3: 1-18. Only after having done this such a general apodictic assertion can be made on an aspect of early-Christian theology/Christology. My basic assumption here is that the Fourth Gospel's contribution will suffice as 'prooftext' only if the Synoptics do not contain and treat this specific aspect.

Such an exegetical excursion on the Baptist's contribution is presented by Peter Richardson in his article entitled 'Gospel traditions in the church of Corinth' (see on pp 301-318, esp pp 306-308). Hengel ought to take notice of this article.

Hengel's appeal in this respect on Johannine writings is all the more odd when in his 'Summa' ( $\mathrm{p}$ 264) he concludes: 'Die dahin stehende (i e behind James' letter HAL) Gedankenwelt ist die der jüdischen Weisheit, verbunden mit prophetischem Pathos und in engster Verflechtung mit der Jesustradition, wie sie uns in Q, bei Mt und $\mathrm{Mk}$ begegnet'. A contradiction exists in his whole argumentation here: On the one hand he puts the letter of James (except for its end) outside the early-Christian line of thought on Jesus' expiatory role, while Jesus is mentioned only twice in the whole letter. On the other hand, James' letter is placed within the main stream of Jesus traditions, as represented exclusively by $\mathrm{Q}, \mathrm{Mk}$ and $\mathrm{Mt}$ ! This dilemma is not at all resolved by Hengel's view point that the letter carries what he calls a 'Doppelcharacter' which comprises two levels and two groups of receptors (see pp 264f).

- Judged in its entirety, this article of Hengel's on James' letter is indeed worth studying.

In his article entitled 'The hermeneutical significance of 1 Cor 2: 6-16' (see pp 328-347) Peter Stuhlmacher pays attention to hermeneutics as it is spelled out by Paul in this passage. He observes that Paul explains here the twofold clarity of the Scriptures, especially the issues of the internal testimony of the Holy Spirit which functions together with the objective clarity of Scripture as a component of Biblical hermeneutics. 
Stuhlmacher offers an illuminating overview of the historical course of the debates in this field of hermeneutical reflection, especially since the Reformation. He continues by an exegetical analysis of 1 Cor 2: 6-16 in the context of 1:18-2: 16 . He pushes the juxtapositioning of believing wisdom and worldly wisdom to its very extremes, grounding this antithesis in the core of the Jesus tradition as it emerges from post-Easter texts such as 1 Cor 8: 16 together with Col 1: 15 and John's prologue. These texts deal with the contrast between creative, redemptive wisdom in Christ and worldly wisdom such as that offered by the law of Moses and those blinded by Satan. The spiritual wisdom mentioned by Paul is not at all from Gnosticism, since it is from God as the risen Christ revealed it to Paul on his road to Damascus. It is also the wisdom which comes by the fear of God as its principle (see Prov 1: 7, 9: 10, 15: 33; Ps 111: 10; Job 28: 28; Old Testament Apocrypha such as Eccles 2: 15f, 15: 1; Test Levi 13: 1; 2 Bar 46: 4-6; Pss Sol 4: 23, 5: 18).

Stuhlmacher correlates this spiritual wisdom with obedience to the law. Over against obedience to the Mosaic law he poses the spiritual wisdom as embodied in and represented by Jesus. He substantiates this view by an appeal on traditions as they had developed from Prov 1: 7, passim, right through to Jesus himself and within the Johannine church (see Mt 11: 27-30/Lk 10: 21f and Jn 1: 1-18), including Paul's contribution in 1 Cor 2: 2-16.

In conclusion Stuhlmacher formulates the hermeneutical implications of this approach and its application in the form of three fundamental hermeneutical principles for a proper understanding of Scripture. In short these are:

- It is not we (exegetes and theologians) who have to determine critically and selectively what the gospel may or may not say, since the gospel itself demands to be received as such and to have its thoughts be explored.

Here Stuhlmacher works with the autonomy (resp the tyranny) of texts witil. out paying any attention whatsoever to the roles of the interpretive community and the creative reader. These important roles receive due attention in the prevailing perceptions of literary critics in their paradigms of speech act theories, aesthetics of reception and reader-response criticism.

- Theological thought is not to be equated without more ado with critical thought, and the historic-critical method is not to be exalted as the theological method. Theological thought is in the first instance listening thought (cursifying HAL) and only then critical thought. It always proceeds from faith in which Scripture's external clarity can be examined and tested by all appropriate scientific exegetical tools. But the internal clarity, bestowed by the Holy Spirit (i e the spiritual wisdom) is nót open to critical analysis (my cursifying again - HAL). 
By asserting this, Stuhlmacher poses a second form of tyranny in exegetical endeavours, namely the power of the own unverifiable subjective conviction(s) of the believing exegete. What happens now if this latter conviction(s) should clash with the results of critical examination on the level of external clarity? Is not theology ultimately made totally subjected to the exegete's own indisputable convictions, putting us back in sheer subjectivism?

- The way to the internal clarity of the Bible's testimony is found only by those who let themselves be interpreted by Scripture and who share in the faith and walk of Christ's church. Stuhlmacher says that this is of necessity the case because Paul says that spiritual knowledge of the gospel is not only a matter of the intellect; it is at the same time also a matter of the heart and of the practical dedication of one's life to Christ and the gospel.

Again Stuhlmacher presents and defends a paradigm wherein the hermeneutical center of gravity is shifted to the subjective spiritual frame of mind and the religious stance of the individual exegete. Since from their very nature these entities lie beyond critical reasoning and since they happen to constitute the real thrust of this paradigm, it almost shuts all doors for an open discussion on hermeneutics and matters of methodology. It also rules out the possibility that a non-believer can make a valid contribution to theological research. This fact, together with the fundamental unverifiability of the results gathered on the level of the internal clarity, pose grave obstructions and even disruptions for the process of scholarly interaction and theological discussion.

These three fundamental hermeneutical principles that Stuhlmacher formulates on account of his excursion on 1 Cor 2: 6-16 apparently constitute a paradigm which is viable and tenable only in a very restricted way. In applying this paradigm provision should always be made for the fact that the impact and value of this paradigm is restricted by the rigorous presuppositions and by the limited set of questions his exegetical method allowed him to ask to the texts.

That this latter observation is valid and even indispensable to general hermeneutics, is proven by the fact that his principles are in actual fact hermeneutical presuppositions. Being so, it is inevitable to ask Stuhlmacher whether he was guided by the principle of the accepted procedure of the hermeneutical spiral, or that he was captured by the process of toutological circular reasoning (i e to assume a hypothesis of hermeneutics and then utilise this assumption in order to prove that the assumption is valid and correct!).

Peder Borgen devotes his article to one of the most hotly debated aspects of the Johannine problem, namely the relationship between John's Gospel and the 
synoptic Gospels. As everyone would know, all the research on this issue was done in search of sources for the Fourth Gospel (Quellenkritik and Traditionsgeschichte) and with a view to explaining the distinctiveness of the Johannine redaction and interpretation of early-Christian traditions (Redaktionsgeschichte).

Borgen rightly draws attention to the new approach to the problem as it emerged since World War II, whereby scholars moved away from accepting the dependence of the Fourth Gospel from the Synoptics, although the Lovain school as lead by $F$ Neirynck still adheres to this view point. Borgen joins hands with those scholars who maintain together with P Gardner Smith (1938) that the Fourth Gospel represents an independent tradition next to the one underlying $Q$ and Mark. This conviction was finally formulated and substantiated at an international symposium at Oxford in 1957 (see the works of its exponents such as JAT Robinson, S Schultz, CH Dodd, cum suis).

In search of traces of such an alleged independent tradition Borgen investigated what he terms 'pre-synoptic usage of gospel material' (see $p$ 80). His working hypothesis is that what Paul had to say on the eucharist in the passage 1 Cor 11:2329(34) (together with 10:3-4, 16-17, 21) stems from and belongs to this layer of tradition. To verify his hypothesis he firstly analyses and compares sentences, phrases, word-pairs and single words in order to prove that Paul and Luke represent a tradition on the eucharist which is different from the one used by Mark and Matthew. He than continues by establishing what kind of agreement might exist between two mutually independent versions of the same tradition, such as represented by Paul in 1 Cor 11 and its synoptic parallels (viz Mk 14: 22-25 and Mt 26: 2628). Since one third to almost a half of the words and phrases in 1 Cor $11: 23 \mathrm{~b}-26$ (together with 10: 3-4, 16-17,21) are similar, he feels justified to assert: 'Between mutually independent versions of units of oral and/or written traditions there may be close verbal agreements in form of sentences, word-pairs, and sets (of words HAL), single words and corresponding variant terms' (see $p$ 81f).

When this assumption is applied as vantage point for a hermeneutical paradigm, Borgen's analysis allows him to identify three structural components, namely:

- the text of the tradition as it was received, preserved and handed on and written down in 1 Cor 11: 23-25;

- the theme spelled out in 1 Cor 11:26;

- the commentary, also paraphrase and application in 1 Cor 11:27-34 (together with 10: 16-17). 
Borgen observes that already in the mid-fifties the biblical stories about the manna and the well (see 1 Cor 10: 21a together with Mt 6: 24, par - HAL) were being applied to the Lord's Supper (see $\mathrm{p} 85$ ). He continues his argumentation by asserting that this usage of eucharistic gospel traditions by Paul helps us to understand John's use of it. Consequently, this assumption helps to substantiate the hypothesis that John draws on oral traditions rather than to utilise the synoptic tradition(s). According to Borgen it is Paul who offers dated evidence for the assumption that gospel traditions independent of the synoptic layer did exist and was utilised, i e by Paul and John.

In following up this line of argumentation, Borgen then analyses Jn 6: $51 \mathrm{~b}-58$ and 5: 1-18. He discovers a total of at least eleven parallels between Paul (1 Cor 11: 24-34; 10: 3-4,16) and John's Gospel (6: 52-58) and detects also the three structural components (as mentioned above). Again he comes to the conclusion that John's method of dealing with traditions and his utilisation thereof closely correspond with what Paul did.

His next step is to make a comparative analysis between, on the one hand, Jn 5: 1-18 (together with 9: 1-14) and synoptic passages such as Mt 12:1-8/ Mk 2: 23-28 (the plucking of ores of grain on the sabbath) and Lk 13: 10-17 (healing of a crippled woman on the sabbath) and on the other hand, 1 Cor 11:26, 27-34. He discovers some agreement in form and even contents between John's Gospel and the Synoptics (e g Jn 5: 8 and Mk 2: 9), but he ascribes this agreement to the usage of 'a stereotyped phrase'. Ultimately then, Borgen adheres to his conviction that the differences between John and the Synoptics are much more greater than the agreements and that John 's Gospel is nearer to Paul's method and even his phraseology. This observation is made despite what he previously established and proved, namely that Paul shows major agreements with at least Mark!

In order to save his argument, he asserts that the agreements between Jn 5: 10 and Mt 12: 2 should be ascribed to the fact that John utilised traditional forms of expression as it was also done when Paul wrote 1 Cor 10: 21 and 11:27-29. Again, the agreements in form and phraseology between John and the Synoptics do not prove any dependence, since both John and the Synoptics followed a traditional structure for a controversial case ( $\mathrm{i}$ e actions on the sabbath - HAL) which is subsequently followed by a judicial dialogue' (see p 89).

In a further effort to save his argument Borgen constitutes a direct relationship between the expository commentaries of Jn 5: 10-18 and those in 1 Cor 11: (26)27-34, asserting that in its entirety the former passage forms a parallel with 1 Cor $11: 23-34$. This analogy is the result of the fact that the same type of expository activity prevailed both within the Johannine community and in Pauline circles. Moreover, 
this agreement also exists with regards to the Sitz im Leben of the two passages, namely the controversy between church and synagogue on issues such as Christology, sabbath observance and the law of Moses. This common Sitz im Leben brought John and Paul together as far as representation of pre-gospel traditions was concerned.

Consequently, Borgen's conclusion on $p 92$ is that $\mathrm{Jn} 5: 1-18$ follows a traditional structure in which a controversial state of affairs concerning the sabbath is followed by a judicial dialogue and that Paul in 1 Cor 11: 23-34 uses the same basic form of a story from the gospel tradition followed by an expository commentary of legal nature. Moreover, he persistently maintains his basic hypothesis pertaining to the independence of John's Gospel from the Synoptics on account of the observation that 'the similarities between the two mutually independent traditions of 1 Cor 11: 23-25 (26) and Mk 14: 22-25 are much more extensive and clearer than they are between Jn 5: 1-18 and the Synoptics'.

In assessing this article, this latter observation offers an appropriate example of the type of problem a critical reader experiences. It is incomprehensible how Borgen can postulate and substantiate John's independence of the Synoptics while he also asserts that 'a more extensive and clearer' similarity exists between 1 Cor 11: 23-25(26) and $M k$ 14: 22-25, while he precisely argues for the same agreement in form and contents between Jn 5: 1-18 and the same passage in 1 Corinthians! Then there is at least a close correspondence between John's Gospel and one of the Synoptics, namely Mark as the oldest of them and whose tradition forms together with Q some sort of source for Mt and Lk.

As far as context and contents are concerned $\mathrm{Jn}$ 5: 1-18 has virtually nothing in common with 1 Cor 11: 23-34. Borgen forced these two passages together in order to suit his hypothesis.

It means an incorrect structurisation to divide Jn 5: 1-18 in two the components of text (vss 1-9) and commentary/expository paraphrasing (vss 10-18). The whole pericope forms part and parcel of one narrative which focuses on the controversy around the sabbath. This passage from John's Gospel does not at all qualify for being a Johannine 'aside'.

Contrary to Borgen's observation, one must maintain that the focal point and thrust of Jn 5: 1-18 is not Christology, but the sabbath controversy. This is precisely what is at stake in the synoptic parallels to this passage to which Borgen refers, namely Mt 12: 1-8, Mk 2: 23-28 and Lk 13: 10-17. Jesus' follow-up discourse in Jn 5: 19-47 about his status and mission exactly deals with his defence against Jews who attacked him because of his healing on the sabbath. This is expressed in vss 16-18 where the Sitz im Leben and theological context of vss $16-18$ are spelled out as being 
the sabbath question and not Christology as such.

Similarities in the phraseology of Paul and John are due to general semiotics as it prevailed then. As a matter of fact, Borgen makes out this case clearly in his analysis and explanation of similarities between John and the Synoptics.

In conclusion I must state that Borgen's attempted solution of a classical aspect of the Johannine problem did not realise the expectations he created. This problem is still unsolved, as he states in the very first sentence of his essay!

His hypothesis about the relatedness of John's Gospel with what he terms pregospel traditions as Paul received and utilised them, is not substantiated and proven at all. Apparently, the reason for this failure is that his assumptions are very much debatable and his documentary evidence is invalid because of his inconsistent argumentation. He overloads the texts by illegitimately superimposing Johannine texts on Pauline ones, and/or vice versa.

$D$ Moody Smith devotes his contribution to the same issue which Borgen addresses, namely the relationship between John's Gospel and the Synoptics. He aligns himself with BS Childs' observations and perceptions in his book on the New Testament as canon (1984).

From the outset Smith clearly puts his cards on the table by crossing swords with the exponents of the historical-critical approach. Over against the latters' approach of understanding and interpreting the Fourth Gospel in its own right and in isolation from the Synoptics and the remainder of the New Testament, he propounds an approach which views the problem from the perspective of the function of John's Gospel and its relationship with the Synoptics within the context of the Christian canon. This means that he opts for a theological paradigm of understanding John's Gospel and its relationships, instead of a historical (i e a historical-critical) one. This means that meaning in Christian exegesis and its interpretation is constituted by the traditional status of biblical writings as part of the Christian canon. As far as the Fourth Gospel is concerned, its original setting and relationship with the Synoptics do not determine its meaning and significance. This Gospel is to be seen in its own light and in terms of the Synoptics and the remainder of the New Testament when these writings became the canon of the Christian church by the end of the second century (see EC Hoskyns 1947). He also appeals to $\mathrm{H}$ Windisch (1926) and RA Culpepper (1982) who maintain the independence of John's Gospel along with the Synoptics in the sense that the former presents a sufficient and complete testimony about Jesus, not playing a supplementary role nor needing to be supplemented. As it is the case with the implied reader, according to Culpepper and literary critics, John's Gospel presupposes and assumes knowledge of personalities and events which are known only from the Synoptics. This does not, however, rule 
out its autonomy.

A major implication of this perception is that no one of the four Gospels can and may provide the key to the understanding of any of the others. As will be clear later, Smith does not succeed in maintaining this hermeneutical rule consistently, especially when he spells out the close connection between John and Paul.

If all issues relating to the Fourth Gospel are to be understood and interpreted in terms of the existence and function of a canon of four Gospels and the other New Testament books by the end of the second century, then the history of the formation of this canon becomes vital for Smith's paradigm. He acknowledges this fact, but maintains that the status of the Fourth Gospel cannot be made subjected to the historical process whereby it became part of the canon and was accepted as such; neither can this status be determined by its apostolic authorship by John. All that is at stake here is that it was part of a developing canon and that the accent should be placed on its own authority as it was heard and received within the early church as being John's Gospel (see the commentary in the Muratorian Fragment and what Eusebius had to say on this matter). Smith agrees with Childs who observes in this respect that only the present canonical shape of this Gospel (as by the year 200 AD) is to be considered as the beginning point and focus of a canonical approach. This implies that the circumstances of the formation of the canon and the controversies around this Gospel's inclusion in the Christian canon are ignored and relativised, and that happens despite its disputability because of 'unaccountable divergencies with the Synopties'. Smith is willing to go along with Käsemann (1968) when he asserts in this respect that John's Gospel 'was domesticated by the church by divorcing it from its original setting and purpose'. However, he rightly stipulates against Childs that ignoring these facts and factors does imply that another basis is laid for the canonical authority of this Gospel than was historically the case.

In working out his canon-theological paradigm Smith investigates the relationship of John's Gospel within the gospel canon. He deems I k and Mk (which is for $90 \%$ included in Matthew's Gospel) as of no immediate importance. As far as $\mathrm{Mt}$ is concerned, he contends that this Gospel begins the Christian gospel canon and John closes it (see p 172 par). He observes that Matthew's theme is the fulfillment of God's righteousness by and through Jesus, the Christ (Messiah) in David's line. This theme runs like a golden thread through Mt and through the whole of the New Testament (see pp 170, 171). As such Matthew's theme becomes the scopus of the entire Christian gospel canon, which means that Smith breaks his hermeneutical rule that no one gospel may provide the key to the understanding of others. This observation about Mt also contradicts what he subsequently has to say about John's relationship with Paul (see below). 
He even elaborates on Matthew's conclusive hermeneutical function within the Christian gospel canon and this canon at large. He states that Matthew's Christology on who the Messiah actually is, namely the fulfillment of the Old Testament and of major basics of Judaism, constitutes a central concept of Mt and in the New Testament and Christianity (see $p$ 171). According to Smith Matthew spells out the pivotal role of the events of the living and reigning Lord Jesus Christ with a view to the New Testament and Christianity. The conclusion is inevitable that within Smith's paradigm Matthew offers in principle some key to understanding the Gospels and even more than that!

With regards to working out further detail on how John's Gospel relates and correlates to Matthew's christological perceptions, Smith creates severe problems for what he previously observed. His ultimate observation in this regard can be epitomised by his statement about Matthew's and John's versions of how Old Testament figures and institutions relate to Jesus, the Messiah. He states: 'John establishes not an absolute contradiction, but a significant and creative tension with Matthew' (see $p$ 173). He goes on by saying that Matthew who stands at the beginning of the Gospel canon, relates Jesus positively to the Old Testament and to the Jewish expectations. Over against Matthew, John stands at the close of this canon. Although he does acknowledge the fulfillment of expectations, he quite explicitly affirms that Jesus is more than this fulfillment and he strongly emphasises the fact of the Jews' rejection of Jesus. Moreover, although the real differences between $\mathrm{Mt}$ and Jn cannot be described in terms of the so-called 'low Christology' and 'high Christology' respectively, 'Matthew differs decisively from John in the way in which Christology is filled out or explained.' This difference comprises the fact that Mt, as elsewhere in the New Testament, draws deeply upon the tradition of Jesus-logia about who the Messiah is and how he teaches the law (Torah) of God's will. John, on the contrary, almost ignores these logia and puts the Jewish law in an ambiguous light, whilst he teaches Christology explicitly. Ultimately, for Matthew and the other Synoptics Christology is present and it is presented as the overall framework into which a Palestinian tradition about Jesus' ministry is fitted. John, on the contrary, 'goes another way entirely': Despite similarities as far as the narrative framework is concerned, his presentation of the speeches of Jesus and of his healing ministry is very much different, since every time he points to himself as the king who works miracles through his supernatural power. Allegiance to him means the termination of relations with the Jews and the synagogue.

Two points of serious criticism are to be raised here.

Firstly, Smith violates a basic element of his own paradigm when he expresses this fundamental differences between $\mathrm{Mt}$ and $\mathrm{Jn}$ about their respective versions and 
perceptions on Christology. If these differences exist (and they surely do!) in the field of Christology as being the "overall framework into which a tradition ... is fitted", then the canon-theological approach as such is principally jeopardised. Smith does not even rescue his paradigm by asserting that Matthew stands at the beginning and John at the close of the gospel canon. Furthermore, his suggestion that Matthew in his unique position and role serves as a key for understanding and interpreting the gospel canon, is also turned upside down by these christological discrepancies.

Secondly, Smith is not consistent in his application of a canon- theological paradigm of understanding. In dealing with Matthew who places Jesus in the Heilsgeschichte (see pp 172f) he works with formula Old Testament quotations in John's Gospel (e g 12: 14-15, 38, 39-40; 13:18, et al) which are 'to be traced to their existence in pre-Gospel traditions'. By this observation he brings historical-critical considerations into his approach, which in principle is a Fremdkörper in his canontheological paradigm. He emphatically stated in the beginning that historical criticism is only a teacher, but not an arbiter (judge) which may determine meaning of the contents of the gospel canon. Instead of being consistent by determining the meaning and significance of these quotations by the end of the process of canonisation of early-Christian writings ( $i$ e end of the second century), he goes backwards to the beginning of this process!

When Smith draws clear similarities between John and Paul, he displaces as it were Matthew's central position and with it the hermeneutic importance of the gospel canon. He asserts that Paul and John unite in their perceiving of Jesus as the eschatological event. For them Jesus is the appearance in history of God's salvation and judgment. Neither of these two witnesses are interested in history and historical issues as such, for their perceptions are properly theologically in nature. Any historical accreditation is ignored and ruled out as being illegitimate, since God's revelation about Jesus is eo ipso self-authenticating and theologically orientated. Without clear reservations and resistance Smith then discusses Bultmann's model which lifts out Paul and John from the canon of the New Testament and isolates them as the bearers of the theological rather than the historical approach (see pp 174f). Together with this Smith seems to concur with Bultmann's viewpoint that the Synoptics are of no importance to him and he (Smith) even states that Bultmann correctly (my italics - HAL) declines to see Paul as presupposing the synoptic Gospels; further, that Bultmann 'may be correct' if he views John exegetically as independent of the synoptic Gospels and presupposing other traditions as sources (see $\mathrm{p}$ 175). He also agrees with Bultmann in labeling Paul and John as the 'twin peaks of theological development within the New Testament' and that 'a theologi-cally 
relevant interpretation of Paul and John takes them out of the canon'.

He then contends himself by only making the following general assessment on Bultmann's contribution: 'Without denigrating the position or insights of Bultmann, it is almost certainly correct and appropriate to observe that we have here a classic instance of the pressing to a logical conclusion of Luther's criterion of what preaches Jesus (was Christum treibet - HAL) as an hermeneutical key' (see p 175). This means a reference to the idea of a canon within a canon and the minimising of the canon as a vehicle of authority. Smith labels this whole idea quite favourably in calling it 'a telling move'. Apart from this, Smith also accepts Käsemann's concept of 'a canonical Paul' (of the kerygma) and 'a historical' one. Consequently, also a 'canonical John' and a 'historical' one.

Again, it is simply incomprehensible how Smith could go along so uncritically with the historical-critical observations and also perceptions of Bultmann, Käsemann and others. This step virtually destroys his own canon-theological approach. I particularly refer to aspects such as lifting out Paul and John from the canon and isolating them as the bearers of theological insights within the New Testament; further, viewing Paul and John as being exegetically independent of the Synoptics and presupposing other traditions as sources (which is a historical-critical observation which does not fit into Smith's paradigm); the putting of John nearer to Paul than to the Synoptics (which contradicts his rule of viewing the Fourth Gospel first of all within the context of the gospel canon); the problems to his whole approach posed by a minimising of the canon and his going back to pre-gospel traditions instead of seeking meaning forwardly in time at the reception of the gospel canon.

Suffice it is to say that one does not know where Smith is moving from this point. For this reason paragraph 5 (pp 175-78) where he spells out the value, function and conclusions of his paradigm of a canon- theological approach, can be deemed null and void. For example, what value does it have to state that John's uncompromising and distinctive individuality and brilliance ... make sense best, and make proper theological sense only when it is viewed in the light of the synoptic Gospels' (see pp 175f)?

In the light of the all the confusion created by Smith's inconsistency, the value and validity of the following concluding observations ( $\mathrm{pp}$ 176-178) should seriously and fundamentally be questioned:

- The canonical status of John, if taken seriously, considerably mitigates the question of John's relationship to the Synoptics. 
* If the canonical status and position of John are assumed as significant data to be reckoned with theologically, the question whether or not John was written in positive cognizance of the Synoptics ... remains an interesting historical question, but ceases to require any particular answer. John stands fourth, last, in the gospel canon, as if it were to be read not only alongside, but after the other three.

- The traditional view that John wrote to supplement and interpret the Synoptics is actually derivative from its canonical status. It reflects an intelligible way of reading John not backwards into its historical origin and purpose, but forwardly in view of its theological and canonical significance.

- Important presuppositions are lacking for an acceptable reading of John if the other Gospels are not taken into consideration. This is the mistake made by historical criticism and even literary critics, which is only a repetition of what happened when the Valentinian Gnostics, Montanists and others misused the Fourth Gospel. According to Raymond Brown (1982), the first epistle of John was written precisely to rectify the Johannine church's misreading of John's Gospel!

- There is little question that the canonical positioning of the Fourth Gospel, which may or may not accord closely with its historically original purpose and setting, affords an important guide or direction for its interpretation within the Christian community.

- We have the Gospel of John first of all within the canon, and that is the primary context for interpretation for Christians who are seeking in this Gospel a word from or about God. Therefore, the New Testament as canon commands and endorses the authority of John's Gospel to the church and to Christians.

* The historical-critical method may be an indispensable teacher, but it is not the final arbiter of meaning.

- Standing together in the canon, the Gospels shed light on one another. As one legitimately reads John in the light of Matthew, and the Synoptics generaliy, one also reads the latter in the light of John. John may be the key that unlocks the other Gospels (Calvin's observation), but the other Gospels also lay down suppositions and groundwork on the basis of which John is to be read.

Obviously, as stated above, these observations are subject to severe questioning. 


\section{CONCLUSION}

Reviewing a theological book which covers many specialised fields and one in which also diverting paradigms and procedures of exposition are represented, is to my mind nowadays an almost impossible task. Therefore I reviewed only those twelve essays which are within my field of special interest and specialisation. The contributions were not judged by perceptions such as 'conservative' and 'liberal', because these quasi-norms are too much biased, self-assertive, absolutistic and obselete.

The common trends underlying these twelve contributions are:

- Each of the twelve scholars presents and applies an approach and a procedure reminiscent of a particular school of exegetes. In a milieu where, in general, methodological tolerance (pluralism of methods) prevails this diversity of approaches were to be expected and they are perfectly acceptable.

- In finally assessing the implementation of individual paradigms, however, it was observed and it is maintained that some scholars followed procedures which do not comply with the requirement of consistency and with general rules of how literature works. Ultimately, the nature of these methodological deficiencies boils down to the errors of reading and interpreting passages out of context or within invalid contexts, and also expounding passages within the overarching paradigm of the unity of the entire New Testament, ignoring a proper historical perspective of how the various New Testament documents were created independently of each other and for various Christian communities/individuals under different circumstances of needs, threatens and worlds of thought. These criticisms apply especially for the essays of Gerald Hawthorne, Otto Betz, Martin Hengel, Peter Stuhlmacher, Peder Borgen and particularly of Moody Smith. The latter's contribution is a classical example of precisely how things should not be done in exegesis and theology.

- In the end my critical review of twelve of the essays in the collection brings one to the point of asserting the thesis that the presentations do not reflect interpretation of traditions IN (i e as spelled out in) the New Testament, but rather diverse interpretations by scholars $O F$ various versions/aspects of early-Christian traditions within the New Testament!

- In any survey of the history of New Testament scholarship and of the results of New Testament research the view points of these twelve scholars and their results of research would only be of marginal value. The lists of titles they referred to and utilised, however, are quite extensive and would be of substantial help for further research. 